\title{
Analisis Sistem Pembelajaran Online XYZ Menggunakan Technology Acceptance Model (TAM)
}

\author{
Triana Elizabeth ${ }^{1 *}$, Tinaliah ${ }^{2}$ \\ ${ }^{1}$ Program Studi Sistem Informasi, ${ }^{2}$ Program Studi Manajemen Informatika \\ Universitas Multi Data Palembang \\ Palembang, Indonesia \\ trianaelizabeth@mdp.ac.id, tinaliah@mdp.ac.id
}

\begin{abstract}
ABSTRAK - Universitas XYZ memiliki suatu Sistem Pembelajaran Online XYZ yang telah diimplementasikan pada tahun 2019 melengkapi sistem yang sebelumnya sudah ada yaitu Sistem Pembelajaran Online dan Interaktif XYZ. Namun, masih belum diketahui apakah Sistem Pembelajaran Online XYZ telah diterima dengan baik oleh dosen maupun mahasiswa. Oleh sebab itu, perlu dilakukan analisis untuk mengetahui bagaimana atau seberapa besar penerimaan dan pemahaman dosen beserta mahasiswa terhadap penggunaan Sistem Pembelajaran Online XYZ. Technology Acceptance Model (TAM) adalah salah satu model yang dapat digunakan untuk mengetahui hal ini. Terdapat 4 variabel yang akan diukur yaitu tingkat kepercayaan terhadap penggunaan Sistem Pembelajaran Online XYZ (perceive usefulness), tingkat kepercayaan bahwa Sistem Pembelajaran Online XYZ akan memudahkan dalam proses perkuliahan dibandingkan sebelum adanya sistem (perceive ease of use), sikap positif atau negatif dari pengguna yaitu dosen dan mahasiswa terhadap Sistem Pembelajaran Online XYZ (attitude toward using), dan penggunaan aktual (actual usage). Angket/ kuesioner disebar ke dosen dan mahasiswa sebagai data utama untuk diproses. Data akan diolah dan dianalisis melalui aplikasi statistik SPSS. Setelah melakukan uji validitas, reliabilitas, dan analisis regresi berganda maka hasilnya adalah 3 hipotesis terbukti benar.
\end{abstract}

\section{Kata Kunci: Regresi Berganda, Reliabilitas, SPSS, TAM, Validitas}

\section{PENDAHULUAN}

Universitas XYZ memiliki visi dimana pada tahun 2040 Universitas XYZ memiliki daya saing global dan inovasi yang berkelanjutan dalam bidang rekayasa dan bisnis yang berbasis pada teknologi informasi. Sedangkan salah satu misi dari Universitas XYZ adalah agar dapat menghasilkan lulusan inovatif, kompeten, dan mempunyai daya saing maka Universitas XYZ melaksanakan proses perkuliahan termasuk belajar dan bimbingan yang berkualitas dengan sarana akademis yang kondusif dan harmonis. Demi mencapai visi dan misinya, maka Universitas XYZ memiliki suatu Sistem Pembelajaran Online yang disingkat SP2-XYZ yang telah diimplementasikan pada tahun 2019 melengkapi sistem yang sebelumnya sudah ada yaitu SP1-XYZ (Sistem Pembelajaran Online dan Interaktif).

Unit Pelaksana Teknis bagian Sistem Informasi (UPT SI) Universitas XYZ telah sangat bekerja keras dalam merancang dan membangun SP2-XYZ sesuai dengan kebutuhan. UP'T SI juga telah menyediakan buku panduan penggunaan SP2-XYZ baik untuk dosen maupun mahasiswa. Selain buku, juga ada video berupa tutorial sehingga memudahkan dosen dan mahasiswa menggunakan Sistem Pembelajaran ini dalam proses perkuliahan. UPT SI juga menyiapkan form pengaduan apabila ada keluhan atau saran-saran terkait Sistem Pembelajaran Online. SP2-XYZ memiliki fitur-fitur yang banyak dan sangat bermanfaat untuk mendukung proses perkuliahan pada semua jurusan di Universitas XYZ.
Aktor atau pengguna utama pengguna SP2-XYZ adalah dosen dan mahasiswa. Bagi dosen, SP2-XYZ memiliki fitur untuk mengatur kursus/ mata kuliah diampu beserta peserta kursus yaitu para mahasiswa. SP2XYZ menyediakan fitur-fitur yang memudahkan dosen untuk mengatur aktivitas perkuliahannya mulai dari memberikan materi perkuliahan melalui berbagai jenis file yang bisa diupload seperti file dokumen seperti modul pembelajaran atau file presentasi, maupun file video yang lebih interaktif. Selain itu, melalui SP2-XYZ dosen juga bisa langsung memberikan tugas kuliah dengan memberikan batas waktu bagi mahasiswa untuk mengumpulkan tugas tersebut dan dapat membuat kuis langsung baik melalui metode essay maupun pilihan ganda. Selain itu, terdapat fitur: kehadiran, feedback/ masukan, forum, obrolan, workshop, dll.

Melalui berbagai fitur-fitur yang ditawarkan pada Sistem Informasi Pembelajaran Online (SP2-XYZ) diharapkan selain membantu dosen maupun mahasiswa dalam proses perkuliahan, tapi juga dapat meningkatkan kualitas pembelajaran perkuliahan. Sampai saat ini, masih belum diketahui apakah Sistem Pembelajaran Online XYZ telah diterima dengan baik oleh dosen maupun mahasiswa. Oleh sebab itu, perlu dilakukan analisis untuk mengetahui bagaimana atau seberapa besar penerimaan dan pemahaman dosen beserta mahasiswa terhadap penggunaan Sistem Pembelajaran Online XYZ dengan cara mengukur perilaku dari penggunanya.

Technology Acceptance Model (TAM) adalah salah satu model yang dapat digunakan untuk mengetahui hal ini. Menurut Davis [1] Technology Acceptance Model (TAM) 
merupakan suatu model penerimaan sistem teknologi informasi yang digunakan oleh masyarakat dan dikembangkan dari Theory of Reason Action yang dikembangkan oleh Ajzen dan Fishbein [2] pada tahun 1980. Empat hal yang akan diukur yaitu tingkat kepercayaan terhadap penggunaan Sistem Pembelajaran Online XYZ (perceive usefulness), tingkat kepercayaan bahwa Sistem Pembelajaran Online XYZ akan memudahkan dalam proses perkuliahan dibandingkan sebelum adanya sistem (perceive ease of use), sikap positif atau negatif dari pengguna yaitu dosen dan mahasiswa terhadap Sistem Pembelajaran Online XYZ (attitude toward using), dan penggunaan aktual (actual usage).

Angket/ kuesioner disebar ke dosen dan mahasiswa sebagai data utama untuk diproses. Menurut Sekaran [3] angket/ kuesioner adalah hasil dari rumusan peneliti berupa daftar pertanyaan yang nantinya dijawab oleh responden yang terpilih. Data akan diolah dan dianalisis melalui aplikasi statistik SPSS. Menurut Dixon [4] SPSS adalah suatu alat untuk melakukan analisis statistic yang digunakan di berbagai bidang dan disiplin ilmu yang berfungsi untuk mengelola data dan menganalisis data.

Terdapat cukup banyak penelitian yang telah dilakukan terkait dengan analisis suatu sistem pembelajaran online yang dapat dijadikan sebagai referensi. Penelitian [5] tentang bagaimana hasil pengukuran kesuksesan terhadap implementasi e-learning menggunakan dua metode yaitu TAM dan UTAUT. Variabel TAM dan juga variabel UTAUT digunakan untuk mengukur hal ini. Responden pada penelitian ini berjumlah 30 mahasiswa dari Fakultas Ekonomi. Hasil dari penelitian ini adalah lebih banyak responden yang menyatakan bahwa implementasi e-learning sukses dibanding dengan yang menyatakan tidak sukses yaitu $68,03 \%$ menyatakan sukses dan 31,07\% menyatakan tidak sukses. Penelitian [6] mengukur penggunaan e-learning dengan TAM menggunakan variable actual usage. Alasan pelaksanaan penelitian ini adalah mengetahui hubungan antara actual usage dan tingkat niat seseorang menggunakan AULA (Airlangga University e-learning Application). Warp PLS digunakan sebagai alat uji. Melalui penelitian yang dilakukan, dapat diketahui bahwa tingkat kepercayaan terhadap penggunaan AULA tidak berpengaruh terhadap penggunaan actual. Selain itu, penggunaan AULA semakin meningkat jika dimotivasi oleh kepercayaan seseorang jika AULA dapat meringankan/ memudahkan proses. Penelitian [7] terkait metode pembelajaran e-learning menggunakan TAM sebagai pembelajaran akuntansi. Pengembangan model pembelajaran e-learning menjadi tujuan sehingga dosen dan mahasiswa dapat dengan mudah mengembangkan matakuliah. Variable yang digunakan adalah semua variable pada TAM serta uji hipotesis menggunakan SEM. Beberapa tahapan pengujian yang telah dilakukan yaitu pengujian validitas dan reliabilitas, pengujian terhadap kriteria model fit dan koefisien laten, keluaran secara tidak langsung dan keseluruhan efek/ dampak menghasilkan informasi bahwa 5 hipotesis yang dikemukakan diterima sedangkan 2 hipotesis lainnya ditolak. Penelitian [8] menggunakan Servqual untuk mengukur kualitas layanan web suatu perguruan tinggi. Penelitian menggunakan 5 dimensi pengukuran yang dimodifikasi yang hasilnya dapat mengetahui bagaimana kualitas dari suatu layanan web akademik yang telah digunakan sebelumnya serta memberikan informasi langkah-langkah perbaikan yang perlu dilakukan untuk meningkatkan layanan web akademik bagi dosen dan mahasiswa.

\section{METODOLOGI}

\section{A. Metode Penelitian}

Penelitian ini dilaksanakan mulai dari proses pengumpulan data awal yang dimulai dari wawancara dan studi literatur dilanjutkan dengan perancangan instrumen dalam bentuk kuesioner online melalui Google Form, penyebaran kuesioner, proses input data ke SPSS, pengolahan data dengan melakukan analisis deskriptif (mean), uji data (validitas dan reliabilitas), uji regresi berganda, dan hasil. Tahapan penelitian ini dapat dilihat pada Gambar 1.

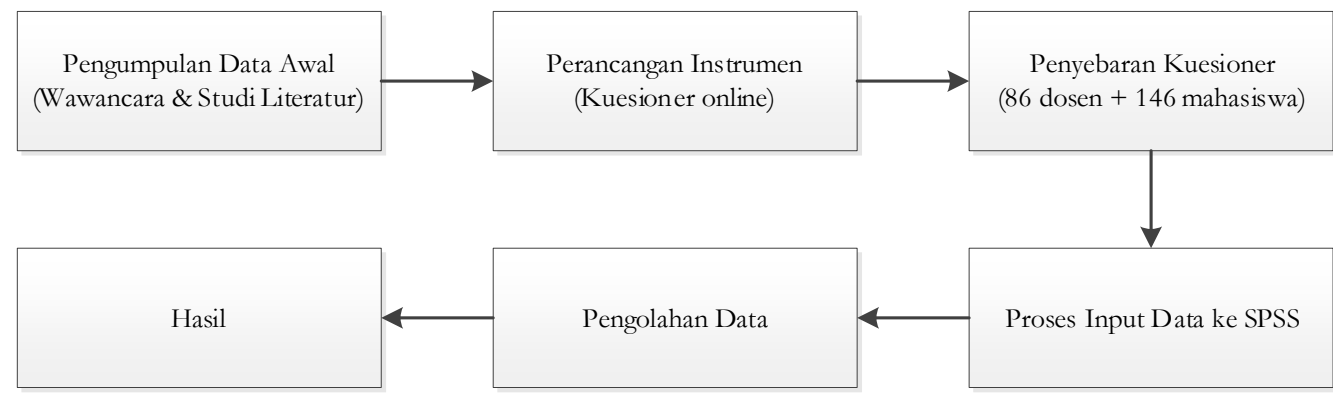

Gambar 1. Tahapan Penelitian

\section{B. Teknik Pengambilan Sampel}

Teknik pengambilan sampel pada penelitian ini menggunakan probability sampling yaitu teknik stratified random sampling. Pemilihan sampel berdasarkan syarat atau kriteria yang sesuai dengan penelitian yaitu dosen dan mahasiswa angkatan 2019 dan angkatan 2020. Total seluruh dosen tetap dan dosen luar biasa terdapat 86 orang dosen. Total jumlah mahasiswa angkatan 2019 dan 2020 ada 468 orang mahasiswa. Jadi total dosen dan mahasiswa adalah 554 orang. Menentukan sampling 
menggunakan rumus Slovin dengan margin error sebesar $5 \%$.

$$
\text { Rumus Slovin: } n=\frac{N}{1+N e^{2}}
$$

Keterangan $\boldsymbol{n}$ menandakan minimal jumlah sampel yang harus diambil, $\boldsymbol{N}$ menandakan banyaknya jumlah populasi keseluruhan, $\boldsymbol{e}$ menandakan besaran margin error. Berdasarkan rumus Slovin [9], dengan jumlah populasi 554 dan margin error sebesar 5\% maka didapat nilai $n$ atau jumlah sampel minimal yang diambil sebesar 232 dimana 86 orang dosen dan 146 orang mahasiswa.

\section{HASIL DAN PEMBAHASAN}

\section{A. Variabel/ Atribut Penelitian}

Terdapat 4 variabel/ atribut yang digunakan dalam penelitian yang kemudian dibagi menjadi menjadi variable independen/ bebas dan variabel dependen/ terikat. Variabel bebas pada penelitian ini adalah tingkat kepercayaan terhadap penggunaan Sistem Pembelajaran Online XYZ (perceive usefulness) dan tingkat kepercayaan bahwa Sistem Pembelajaran Online XYZ akan memudahkan dalam proses perkuliahan dibandingkan sebelum adanya sistem (perceive ease of use). Sedangkan variable terikat pada penelitian ini adalah sikap positif atau negatif dari pengguna yaitu dosen dan mahasiswa terhadap Sistem Pembelajaran Online XYZ (attitude toward using) dan penggunaan aktual (actual usage).
Menurut Davis [1], tingkat kepercayaan terhadap penggunaan Sistem Pembelajaran Online XYZ (perceive usefulness) dapat diketahui menggunakan beberapa indikator yang terkait seperti pekerjaan yang dipercepat (work more quickly), pekerjaan yang dipermudah (makes job easier), kinerja yang semakin berkembang (improve the job performance), produktivitas ditingkatkan (increase productivity), keefektifan (effectiveness), dan kemanfaatan (usefulness). Sedangkan tingkat kepercayaan bahwa Sistem Pembelajaran Online XYZ akan memudahkan dalam proses perkuliahan dibandingkan sebelum adanya sistem (perceive ease of use). Menurut Davis [1] dapat diukur melalui indicator tidak sulit dipelajari (easy to learn), dapat dikontrol dengan baik (controllable), jelas dan mudah dimengerti (clear and understandable), mudah disesuaikan (flexible), dan mudah menjadi mahir (easy to become skillfull). Menurut Ajzen dan Fishbein [2] sikap positif atau negatif dari pengguna yaitu dosen dan mahasiswa terhadap Sistem Pembelajaran Online XYZ (attitude toward using) dapat diukur melalui 5 standard yaitu: menjadi lebih baik atau menjadi lebih buruk (good or bad), menjadi lebih bijak atau menjadi lebih bodoh (wise or foolish), menyenangkan atau tidak menyenangkan (favorable or unfavorable), berdampak baik atau berdampak buruk (beneficial or harmful). Menurut Davis [1] variabel actual usage dapat diukur melalui berapa sering/ frekuensi penggunaan dan berapa lama/ durasi waktu penggunaan. Secara ringkas variabel/ atribut dan indikator yang digunakan dalam penelitian ini dapat dilihat pada Tabel 1.

Tabel 1. Variabel/ Atribut Penelitian

\begin{tabular}{|c|c|c|c|}
\hline No & Variabel & Definisi & Indikator \\
\hline 1 & Attitude toward using & $\begin{array}{l}\text { Sikap positif yaitu menerima atau } \\
\text { sikap negatif yaitu menolak dari } \\
\text { pengguna yaitu dosen dan } \\
\text { mahasiswa terhadap penggunaan } \\
\text { Sistem Pembelajaran Online XYZ }\end{array}$ & $\begin{array}{l}\text { - Menjadi lebih baik atau menjadi lebih buruk (good or bad) } \\
\text { - Menjadi lebih bijak atau menjadi lebih bodoh (wise or foolish) } \\
\text { - Menyenangkan atau tidak menyenangkan (favorable or unfavorable) } \\
\text { - Berdampak baik atau berdampak buruk (beneficial or harmful) }\end{array}$ \\
\hline 2 & Actual usage & $\begin{array}{l}\text { Perilaku pengguna yaitu dosen dan } \\
\text { mahasiswa atas penggunaan } \\
\text { Sistem Pembelajaran Online XYZ } \\
\text { secara aktual }\end{array}$ & $\begin{array}{l}\text { - Saya menggakses SP2-XYZ setiap hari } \\
\text { - Saya menginput aktivitas perkuliahan di SP2-XYZ setiap hari } \\
\text { - Saya mengakses dan mengecek SP2-XYZ setiap hari meskipun hari libur } \\
\text { - Saya mengakses SP2-XYZ minimal } 10 \text { menit setiap kali akses }\end{array}$ \\
\hline 3 & Perveived usefulness & $\begin{array}{l}\text { Tingkat kepercayaan pengguna } \\
\text { yaitu dosen dan mahasiswa } \\
\text { terhadap penggunaan Sistem } \\
\text { Pembelajaran Online XYZ }\end{array}$ & $\begin{array}{l}\text { - Pekerjaan yang dipercepat (work more quickly) } \\
\text { - Pekerjaan yang dipermudah (makes job easier) } \\
\text { - Kinerja yang semakin berkembang (improve the job performance) } \\
\text { - Produktivitas ditingkatkan (increase productivity) } \\
\text { - Keefektifan (effectiveness) } \\
\text { - Kemanfaatan (usefulness) }\end{array}$ \\
\hline 4 & Perveived ease of use & $\begin{array}{l}\text { Tingkat kepercayaan bahwa Sistem } \\
\text { Pembelajaran Online XYZ akan } \\
\text { memudahkan dalam proses } \\
\text { perkuliahan dibandingkan sebelum } \\
\text { adanya sistem }\end{array}$ & $\begin{array}{l}\text { - Tidak sulit dipelajari (easy to learn) } \\
\text { - Dapat dikontrol dengan baik (controllable) } \\
\text { - Jelas dan mudah dimengerti (clear and understandable) } \\
\text { - Mudah disesuaikan (flexible) } \\
\text { - Mudah menjadi mahir (easy to become skillfull) }\end{array}$ \\
\hline
\end{tabular}

\section{B. Hipotesis Penelitian}

Gambar 2 memperlihatkan tentang kerangka konseptual penelitian yang diambil berdasarkan teori Davis [1] tahun 1989.

Pada gambar 2, diterangkan bahwa pada penelitian ini akan diuji bagaimana pengaruh variabel tingkat kepercayaan terhadap penggunaan Sistem Pembelajaran Online XYZ (perceive usefulness) dan variabel tingkat kepercayaan bahwa Sistem Pembelajaran Online XYZ akan memudahkan dalam proses perkuliahan dibandingkan sebelum adanya sistem (perceive ease of use) terhadap sikap positif atau negatif dari pengguna yaitu dosen dan mahasiswa terhadap Sistem Sistem Pembelajaran Online XYZ (attitude toward using). Selain itu juga diuji bagaimana pengaruh variabel sikap positif atau negatif dari pengguna yaitu dosen dan mahasiswa terhadap Sistem Sistem Pembelajaran Online XYZ (attitude toward using) terhadap penggunaan aktual (actual 
usage). Sehingga terdapat 3 hipotesis yang digunakan dalam penelitian ini, yaitu:

H1: perceive usefulness berpengaruh signifikan terhadap attitude toward using;

$\mathrm{H} 2$ : perceive ease of use berpengaruh signifikan positif terhadap attitude toward using;

H3: attitude toward using berpengaruh signifikan positif terhadap actual usage.

\section{Hasil Pengujian Validitas}

Menurut Arikunto [10] jika hasil " $r$ " hitung lebih besar dari " $r$ " tabel maka indikator tersebut dikatakan valid jika sebaliknya maka indikator tersebut tidak valid. Pengukuran validitas setiap variabel pada penelitian ini dilakukan dengan menguji pertanyaan pada 232 orang dosen dan mahasiswa. Validitas instrumen dicari dengan menghitung nilai korelasi Pearson Product Moment (PPM) dalam program SPSS. Berdasarkan hasil validitas, terdapat 3 pertanyaan yang tidak valid. Oleh sebab itu, 3 pertanyaan yang tidak valid tidak diikutsertakan pada analisis selanjutnya

\section{Hasil Pengujian Reliabiltas}

Menurut Ghozali [11] jika memberikan nilai $\alpha>0,60$ maka variabel dapat dikatakan reliabel jika sebaliknya maka variable tersebut tidak reliabel. Hasil uji reliabilitas pada Tabel 2.

Tabel 2 memperlihatkan bahwa semua variabel penelitian reliabel. Hal ini dikarenakan semua variable yang diuji memiliki nilai Cronbach $A \not p h a>0,60$ atau rata rata nilai untuk semua variable diatas 0,80 .

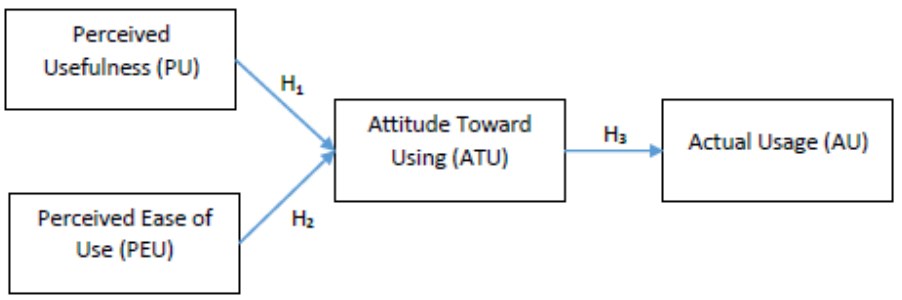

Gambar 2. Kerangka Konseptual Penelitian

Tabel 2. Model Description

\begin{tabular}{lrrl}
\hline Variabel & Cronbach Alpha & Standard reliabilitas & Keterangan \\
\hline Perceive usefulness (PU) & .990 & 0.6 & Reliabel \\
Perceive ease of use (PEU) & .841 & 0.6 & Reliabel \\
Attitude toward use (ATU) & .917 & 0.6 & Reliabel \\
Actual Usage (AU) & .932 & 0.6 & Reliabel \\
\hline
\end{tabular}

\section{E. Hasil Penelitian}

Analisis data pada penelitian ini menggunakan analisis regresi berganda dengan bantuan SPSS. Persamaan umum dari regresi linier adalah sebagai berikut:

$$
\begin{aligned}
& Y 1=a+b 1 X 1+b 2 X 2+e \\
& Y 2=a+b 3 Y 1+e
\end{aligned}
$$

Keterangan persamaan:

a. Y1 menandakan sikap positif atau negatif dari pengguna yaitu dosen dan mahasiswa terhadap Sistem Sistem Pembelajaran Online XYZ (attitude toward using);

b. Y2 menandakan perilaku pengguna yaitu dosen dan mahasiswa atas penggunaan Sistem Pembelajaran Online XYZ secara aktual;

c. X1 menandakan tingkat kepercayaan bahwa Sistem Pembelajaran Online XYZ akan memudahkan dalam proses perkuliahan dibandingkan sebelum adanya sistem (perceive ease of use);

d. X2 menandakan tingkat kepercayaan terhadap penggunaan Sistem Pembelajaran Online XYZ (perceive usefulness);

e. A menandakan konstanta;

f. B menandakan koefisien regresi;

g. E menandakan error/ Tingkat kesalahan.
Berdasarkan persamaan regresi berganda yang didapat, maka selanjutnya dilakukan uji koefisien determinasi yang merupakan salah satu nilai statistic untuk mengukur seberapa jauh kemampuan semua variable bebas yaitu tingkat kepercayaan terhadap penggunaan Sistem Pembelajaran Online XYZ (perceive usefulness) dan tingkat kepercayaan bahwa Sistem Pembelajaran Online XYZ akan memudahkan dalam proses perkuliahan dibandingkan sebelum adanya sistem (perceive ease of use) menjelaskan varians dari variable terikat yaitu sikap positif atau negatif dari pengguna yaitu dosen dan mahasiswa terhadap Sistem Sistem Pembelajaran Online XYZ (attitude toward using). Hasil nilai koefisien determinasi yaitu " $r$ " Square yang didapat adalah sebesar 0,809 . Hasil ini menunjukkan bahwa variable terikat dapat dijelaskan oleh variabel bebas sebesar $80,9 \%$ sedangkan $19,1 \%$ dijelaskan oleh faktor-faktor lain diluar variabel bebas.

Berikutnya adalah mendapatkan informasi tentang sejauh mana pengaruh dari masing-masing variabel bebas/ independen dapat secara individu signifikan terhadap variable terikat/ dependen dengan melakukan uji parsial " $t$ ". Berdasarkan uji parsial " $t$ ", terlihat bahwa variabel tingkat kepercayaan bahwa Sistem Pembelajaran Online XYZ akan memudahkan dalam proses perkuliahan dibandingkan sebelum adanya sistem (perceive 
ease of use - PEU) berpengaruh terhadap variabel sikap positif atau negatif dari pengguna yaitu dosen dan mahasiswa terhadap Sistem Sistem Pembelajaran Online $\mathrm{XYZ}$ (attitude toward using-ATU) karena nilai signifikansi dibawah 0.05 atau sebesar 0.000. Begitu pula dengan variabel tingkat kepercayaan terhadap penggunaan Sistem Pembelajaran Online XYZ (perceive usefulness-PU) terbukti berpengaruh signifikan terhadap variabel sikap positif atau negatif dari pengguna yaitu dosen dan mahasiswa terhadap Sistem Sistem Pembelajaran Online XYZ (attitude toward using-ATU) dengan nilai signifikansi 0.000 . Perceive usefulness menerangkan tingkat seberapa jauh seseorang percaya bahwa dengan menggunakan Sistem Pembelajaran Online (SP2-XYZ) dapat meningkatkan kinerja dalam pekerjaannya. Berdasarkan hasil ini, maka dapat diketahui bahwa dosen maupun mahasiswa memiliki kepercayaan yaitu dengan menggunakan SP2XYZ maka dapat meningkatkan kinerjanya terutama dalam hal proses perkuliahan sehingga hipotesis 1 terbukti benar. Semakin tinggi skor variable perceive ease of use, maka semakin tinggi penggunaan SP2-XYZ berdasarkan persepsi penggunanya. Melalui hasil ini maka dapat diketahui bahwa dosen maupun mahasiswa sering menggunakan SP2-XYZ yang menunjukkan bahwa sistem ini tidak sulit dipelajari, dapat dikontrol dengan baik, jelas dan mudah dimengerti, mudah disesuaikan, mudah menjadi mahir oleh dosen maupun mahasiswa sehingga hipotesis 2 terbukti benar.

Langkah berikutnya mendapatkan persamaan regresi untuk hipotesis 3 yaitu sikap positif atau negatif dari pengguna yaitu dosen dan mahasiswa terhadap Sistem Sistem Pembelajaran Online XYZ (attitude toward usingATU) berpengaruh signifikan positif terhadap actual usage. Berdasarkan hasil uji, diketahui bahwa hipotesis 3 terbukti dimana sikap yang positif dapat menghasilkan penerimaan pada penggunaan. Sikap pengguna yaitu dosen dan mahasiswa yang tinggi akan mempengaruhi tingginya kecendrungan dalam penggunaan actual dan sebaliknya dengan sikap yang rendah maka akan mempengaruhi rendahnya penggunaan actual.

Setelah dilakukan pengumpulan data dan analisis, didapatkan temuan yang merupakan hasil dari pengolahan data penelitian. Temuan pertama terkait dengan jawaban dari responden dosen dan mahasiswa pada setiap variabel yang menghasilkan nilai rata-rata yang didapat dari setiap pertanyaan, setiap pertanyaan dinilai dengan memilih $1 / 2 / 3 / 4 / 5$ dimana nilai 1 nilai terendah dan nilai 5 nilai tertinggi. Berdasarkan 60 pertanyaan, nilai rata tertingginya adalah 4,87 pada pertanyaan: "Menurut saya SP2-XYZ memudahkan proses belajar mengajar dalam perkuliahan". Sedangkan nilai rata terendahnya adalah 2,59 pada pertanyaan: "Terjadi kesalahan pada SP2-XYZ yang tidak dapat diprediksi”.

Temuan berikutnya adalah hasil dari pengujian validitas dan relibilitas, hal ini diujikan untuk meyakinkan bahwa alat ukur yang digunakan adalah tepat dan hasil yang didapatkan konsisten. Hasil validitas ditemukan ada 3 pertanyaan yang tidak valid sehingga tidak digunakan pada proses analisis berikutnya. Hasil reliabilitas menerangkan bahwa semua variable penelitian memiliki nilai $\alpha>0,60$ sehingga semua variable yaitu tingkat kepercayaan terhadap penggunaan Sistem Pembelajaran Online XYZ (perceive usefulness), tingkat kepercayaan bahwa Sistem Pembelajaran Online XYZ akan memudahkan dalam proses perkuliahan dibandingkan sebelum adanya sistem (perceive ease of use), sikap positif atau negatif dari pengguna yaitu dosen dan mahasiswa terhadap Sistem Sistem Pembelajaran Online XYZ (attitude toward using), dan penggunaan aktual (actual usage) adalah reliabel.

Langkah selanjutnya adalah menandai mana yang merupakan variabel bebas dan mana yang merupakan variabel terikat. Variabel bebasnya adalah tingkat kepercayaan terhadap penggunaan Sistem Pembelajaran Online XYZ (perceive usefulness-PU), dan tingkat kepercayaan bahwa Sistem Pembelajaran Online XYZ akan memudahkan dalam proses perkuliahan dibandingkan sebelum adanya sistem (perceive ease of use$P E U)$. Sedangkan variabel terikatnya adalah sikap positif atau negatif dari pengguna yaitu dosen dan mahasiswa terhadap Sistem Sistem Pembelajaran Online XYZ (attitude toward using-ATU), dan penggunaan aktual (actual usage-AU). Dilakukan 3 kali pengujian regresi untuk menguji 3 hipotesis apakah terbukti benar atau tidak. Hipotesis yang pertama adalah perceive usefulness (PU) berpengaruh signifikan terhadap attitude toward using (ATU). Hipotesis yang kedua adalah perceive ease of use (PEU) berpengaruh signifikan positif terhadap attitude toward using (ATU) dan hipotesis yang terakhir adalah attitude toward using (ATU) berpengaruh signifikan positif terhadap actual usage (AU). Hasilnya adalah semua hipotesis baik hipotesis 1, hipotesis 2, dan hipotesis 3 semuanya terbukti benar.

\section{KESIMPULAN}

Penelitian ini dilakukan untuk melakukan analisis terhadap Sistem Pembelajaran Online XYZ (SP2-XYZ) menggunakan Technology Acceptance Methodology (TAM). Terdapat 4 variabel yang digunakan yang dibedakan menjadi variable bebas dan variable terikat. Variabel bebasnya adalah tingkat kepercayaan terhadap penggunaan Sistem Pembelajaran Online XYZ (perceive usefulness-PU), dan tingkat kepercayaan bahwa Sistem Pembelajaran Online XYZ akan memudahkan dalam proses perkuliahan dibandingkan sebelum adanya sistem (perceive ease of use-PEU). Sedangkan variable terikatnya adalah sikap positif atau negatif dari pengguna yaitu dosen dan mahasiswa terhadap Sistem Sistem Pembelajaran Online XYZ (attitude toward using- $A T U$ ), dan penggunaan aktual (actual usage- $A U$ ). Terdapat 3 hipotesis yang akan diujikan dalam penelitian ini yaitu: perceive usefulness (PU) berpengaruh signifikan terhadap attitude toward using (ATU), perceive ease of use (PEU) berpengaruh signifikan positif terhadap attitude toward using (ATU), dan attitude toward using (ATU) berpengaruh signifikan positif terhadap actual usage (AU). Berdasarkan hasil uji validitas terdapat 3 pertanyaan yang tidak valid dan tidak diikut sertakan dalam proses analisis berikutnya. Beradasarkan uji reliabilitas semua variabel yang diujikan terbukti 
reliabel. Berdasarkan hasil uji pengelolaan dan analisis data/ regresi berganda menggunakan SPSS maka hasilnya semua hipotesis yang dikemukakan terbukti benar.

\section{DAFTAR PUSTAKA}

[1] F. D. Davis, "Davis 1989.pdf," MIS Quarterly, vol. 13, no. 3. 1989.

[2] I. Ajzen, M. Fishbein, I. Atomic, E. Agency, T. Federal, and T. Commission, "Theory of reasoned/Theory of planned behavior," Soc. Psychol. (Gott)., vol. 2007, 1980.

[3] U. Sekaran, "Data Primer \& Sekunder," in Research Methods For Business (Metode Penelitian Untuk Bisnis), 2011.

[4] P. Dixon and P. Woolner, "Quantitative Data Analysis: Using SPSS," in Research Methods in Educational Leadership \& Management, 2016.

[5] O. J. F. Wassalam, R. Umar, and A. Yudhana, "Pengukuran Kesuksesan Implementasi ELearning dengan Metode TAM dan UTAUT," J. Edukasi dan Penelit. Inform., vol. 6, no. 1, 2020, doi: 10.26418/jp.v6i1.37938.
[6] R. N. Rahmawati and I. M. Narsa, "Penggunaan elearning dengan Technology Acceptance Model (TAM)," J. Inov. Teknol. Pendidik., vol. 6, no. 2, 2019, doi: $10.21831 /$ jitp.v6i2.26232.

[7] J. Iqbal and A. -, "Metode Pembelajaran E-Learning Menggunakan Technology Acceptance Modelling (TAM) Untuk Pembelajaran Akuntansi," InFestasi, vol. 14, no. 2, 2019, doi: 10.21107/infestasi.v14i2.4856.

[8] M. Mulyati, A. Aryo P, and D. Pandora K, "Pengaruh Kualitas Sistem Dan Informasi Pada Sistem Informasi Pembelajaran Online Terhadap Minat Pengguna Dan Penggunaan Sistem (Studi Kasus: Simponi Amik Mdp, Stmik Gi Mdp Dan Stie Mdp),"J. TAM (Technol. Accept. Model), vol. 8, 2017.

[9] D. Sugiyono, Metode penelitian kuatintatif, kualitatif dan R \& D / Sugiyono. 2018.

[10] S. Arikunto, Prosedur Penelitian Ilmiah. 2010.

[11] I. Ghozali, Aplikasi Analisis Multivariete IBM SPSS. 2016. 